\title{
Editorial: A Singular Practice
}

The elements of D. W. Hamlyn's latest book ${ }^{1}$ do not hang together, but a sufficient number of them hang separately to add up to something like the work he set out to write:

As far as I know, there has been no previous attempt, certainly no recent attempt, to write a history of philosophical practice. Yet it is probable that what philosophers do is as much a puzzle to the average person, even the average educated person, as what they think.

Professor Hamlyn is right to acknowledge that the bones of his book amount to a somewhat sketchy history of philosophy on which he has hung the vignettes and snapshots, the portrait drawings and scenepaintings of which his 'history of philosophy as an institution, not a set of beliefs' mainly consists. The portraits are of the great thinkers, from the earliest Greeks to the present day. The scenes are sometimes of battles between warring schools. Much attention is given to universities and the methods and content of their philosophical teaching and research. These strains become more lively when they concern recent enough generations to involve practical as well as historical disagreements and debates.

Nothing can be fully considered in 180 pages covering so many centuries and so many lands and peoples. One theme that is relatively fully treated is the distinction between amateur and professional thinkers and teachers. The distinction is linked to the notion of technicality, and is rightly imported into Professor Hamlyn's brief account of the institution and development of philosophical societies and philosophical journals, mainly originating from the late nineteenth century. In particular, he gives an account of the Mind Association and its journal Mind, the Aristotelian Society and its Proceedings, and the Royal Institute of Philosophy and this journal.

Though Professor Hamlyn attends to some of the complexities of the issues, he seems too readily to accept things as they are rather than to join in the fight - in which the Institute and its journal are still actively engaged-against 'needless technicality'. It still needs to be said that the struggle against technicality is not the same as the defence of amateurism, even in the best sense of the word. Even the most highly 'professional' papers in Philosophy are improved by due attention to the motto on the masthead.

${ }^{1}$ Being a Philosopher: The History of a Practice, by D. W. Hamlyn (London: Routledge, £25.00.) 


\section{Editorial}

The name of Jacques Derrida occurs only once in this book. That shows what professional opportunism is employed by Routledge when they enclose a press release with our review copy:

In the wake of the Derrida fracas at Cambridge, Being a Philosopher takes a timely look at an often paradoxical practice. Socrates was put to death for it; Aquinas was kidnapped because of it; Leibniz and Spinoza refused university chairs in it; in America, Russell was deemed morally unfit for it. In this first history of the practice of philosophy, D. W. Hamlyn takes us from ancient Greece to the present day to demonstrate the very different roles of philosophers over the centuries, and their often unusual relationship with the institution of philosophy itself.

Jacques Derrida is not the first to have had problems with universities.

An additional enclosure is an outline map to guide the reader to five of the philosophers pictured in a Cambridge Moral Sciences Club photograph dating from 1913 or thereabouts: Russell, Moore, McTaggart, James Ward and W. E. Johnson. The photograph is a cover illustration, occupying front and back and spine. It is a pity that the club is misnamed as the Moral Science Club, and a smaller pity that paraphernalia is treated as a singular noun. It is a singular book. 